\title{
Species of the genera Oxydirus, Dorylaimellus (Axodorylaimellus), Laimydorus and Rhabdolaimus from rivers in the Kruger National Park (Nematoda: Dorylaimida and Araeolaimida)
}

\author{
ANNELIZE BOTHA and J. HEYNS
}

\begin{abstract}
Botha, Annelize and J. Heyns. 1993. Species of the genera Orydirus, Dorylaimellus (A.rodorylaimellus), Laimvdorus and Rhabdolaimus from rivers in the Kruger National Park (Nematoda: Dorylaimida and Araeolaimida). Koedoe 36(1): 49-60. Pretoria. ISSN 0075-6458.
\end{abstract}

\begin{abstract}
Descriptions are given of Orydirus gangeticus Siddiqi. 1966. Laimydorus africamus spec. nov. and Rhabdolaimus terrestris De Man, 1880, recorded for the first time from South Africa. New distribution records are given for Dorylaimellus (Axodorylaimellus) cafficae (Kruger. 1965). Additional information is given and morphometric data are tabulated and where appropriate, illustrations are also given.
\end{abstract}

Key words: Nematoda, Orydirus, Dorylaimellus (Axodorylamellus), Laimydorus. Rhabdolaimus, taxonomy, South Africa, Kruger National Park.

Annelize Botha and J. Heyns. Department of Zoology, Rand Afrikans University. P.O. Bo.x 524. Auckland Park, 2006 Republic of South Africa.

\section{Introduction}

This is the fifth in a series of papers on nematodes from rivers in the Kruger National Park. The previous papers (Botha \& Heyns 1991, 1992a, 1992b, 1992c), dealt with species of various genera from these rivers. The present paper reports on species of Orydirus, Dorylaimellus (Axodorylaimellus), Laimydorus and Rhabdolaimus.

\section{Materials and Methods}

Specimens were killed by gentle heat, fixed in FAA, processed into glycerine by Thorne's slow method, and mounted on permanent slides. Measurements and drawings were done with the aid of a Zeiss Standard 18 research microscope equipped with a drawing tube. All measurements, except the total body length which is in millimeter, are given in micrometers in the tables as well as in the text. Curved structures, eg. spicules, were measured along the curved median line.

All specimens are deposited in the collection of the Department of Zoology, Rand Afrikaans University, Johannesburg.

\section{Descriptions}

Family: Oxydiridae Thorne, 1964

Oxydirus gangeticus Siddiqi. 1966 (Fig. 1A-I).

Morphometric data in Table 1 .

Female

Medium-sized nematode with slender body. Heat-relaxed body posture almost straight (Fig. 1I). Cuticle thin: 1,5-2 $\mu \mathrm{m}$ on the neck; $2-2,5 \mu \mathrm{m}$ at mid-body; and $3-4 \mu \mathrm{m}$ on dorsal side of tail. Cuticle with faint transverse striations rather more prominent towards neck. Cuticle thickened at anterior end. Lateral chords about one fifth body diameter at base of oesophagus, not very prominent. Lateral, ventral and dorsal body pores obscure, except for the anteriormost two or three pores which are distinct.

Lip region confluent with the body and about one fourth as wide as body at base of oesophagus. Lips rounded and amalgamated (Fig. 1A-C). Amphid stirrup-shaped, its aperture 
Table 1

Morphometric characters of Oxydirus gangeticus Siddiqi, 1966

\begin{tabular}{|c|c|c|c|}
\hline Locality & Sabie River & \multicolumn{2}{|c|}{$\begin{array}{l}\text { Type population } \\
\text { (According to Siddiqi, 1966) }\end{array}$} \\
\hline$n$ & 10 Females & Holotype & 3 Females \\
\hline $\mathrm{L}(\mathrm{mm})$ & $1,57(1,47-1.68)$ & 1,57 & $1,34-1,66$ \\
\hline a & $49.4(46,9-52,5)$ & 42 & $41-45$ \\
\hline b & $6,4(6,0-6,7)$ & 6,4 & $6,0-6,4$ \\
\hline c & $5,8(5,1-6,9)$ & 7 & $6-7$ \\
\hline \multirow{2}{*}{$\begin{array}{l}\mathrm{c}^{\prime} \\
\mathrm{V} \%\end{array}$} & $14,2(12,3-15,6)$ & - & - \\
\hline & $37,3(30,9-39,9)$ & 37 & $35-37$ \\
\hline Lip region width & $8(7-9)$ & \multicolumn{2}{|c|}{-} \\
\hline Odontostyle length & $7(5,5-8)$ & \multicolumn{2}{|c|}{$6-7$} \\
\hline Guiding ring from anterior end & $6(5-7)$ & \multicolumn{2}{|c|}{-} \\
\hline \multirow{2}{*}{$\begin{array}{l}\text { Nerve ring from anterior end } \\
\text { Basal oesophageal bulb length }\end{array}$} & $97(94,5-99)$ & \multicolumn{2}{|c|}{-} \\
\hline & $108(99-129)$ & \multicolumn{2}{|c|}{115} \\
\hline Basal oesophageal bulb width & $13(12-15)$ & \multicolumn{2}{|c|}{19} \\
\hline Oesophagus length & $247.5(230-275)$ & \multicolumn{2}{|c|}{ - } \\
\hline \multirow{2}{*}{$\begin{array}{l}\text { Body width at vulva } \\
\text { Tail length }\end{array}$} & $32(28-34,5)$ & \multicolumn{2}{|c|}{-} \\
\hline & $273(242,5-304)$ & \multicolumn{2}{|c|}{-} \\
\hline $\begin{array}{l}\text { Tail length } \\
\text { Anal body diameter }\end{array}$ & $19(18-20,5)$ & \multicolumn{2}{|c|}{ - } \\
\hline Rectum length & $25,5(24-29)$ & \multicolumn{2}{|c|}{ - } \\
\hline Prerectum length & $129.5(70.5-174)$ & \multicolumn{2}{|c|}{ - } \\
\hline $\mathrm{L}^{\prime}$ & $1.30(1,18-1,44)$ & \multicolumn{2}{|c|}{ - } \\
\hline $\begin{array}{l}a^{\prime} \\
b^{\prime}\end{array}$ & $40,8(38,1-42)$ & \multicolumn{2}{|c|}{-} \\
\hline$b^{\prime}$ & $5,3(5,0-6,0)$ & & \\
\hline $\mathrm{V} \%$ & $45,9(43,7-48,4)$ & & \\
\hline $\mathrm{L}^{\prime}=$ total body length - tail length & $a^{\prime}=\frac{L^{\prime}}{}$ & & \\
\hline$L^{\prime}=$ & $\begin{array}{l}\text { width of body a } \\
\text { length of bod }\end{array}$ & erior end to & \\
\hline $\mathrm{b}^{\prime}=\overline{\text { length of oesophagus }}$ & & & \\
\hline
\end{tabular}

about two-thirds lip region width. Odontostyle short and thin, its length slightly less than lip region width. Guiding ring single and weakly sclerotized. Odontophore not very well developed, short and slightly expanded at its base. Anterior part of oesophagus which surrounds odontophore set off from rest of oesophagus by a shallow constriction. Oesophagus a slender tube, enlarging a little behind its middle to form a strongly muscular cylindroid bulb, which occupies $42-47 \%$ of total neck length. Basal bulb surrounded by a relatively well-developed spiral muscular sheath. Cardia tongue-shaped, 7-12 $\mu \mathrm{m}$ in length. Nerve ring well developed, situated at $99,5-129 \mu \mathrm{m}$ from anterior end. Oesophageal gland nuclei and their openings obscure.

Intestinal cells packed with small to mediumsized greenish granules; intestine about eight cells in circumference. Junction between intestine and prerectum distinct. Sphincter at junction of prerectum and rectum not clearly observed in all specimens. Much variation in length of prerectum; 3,5-9,2 times anal body diameter. Rectum length about 1,2-1,6 times anal body diameter. Tail elongate - filiform with acute terminus (Fig. 1E \& F). Caudal 


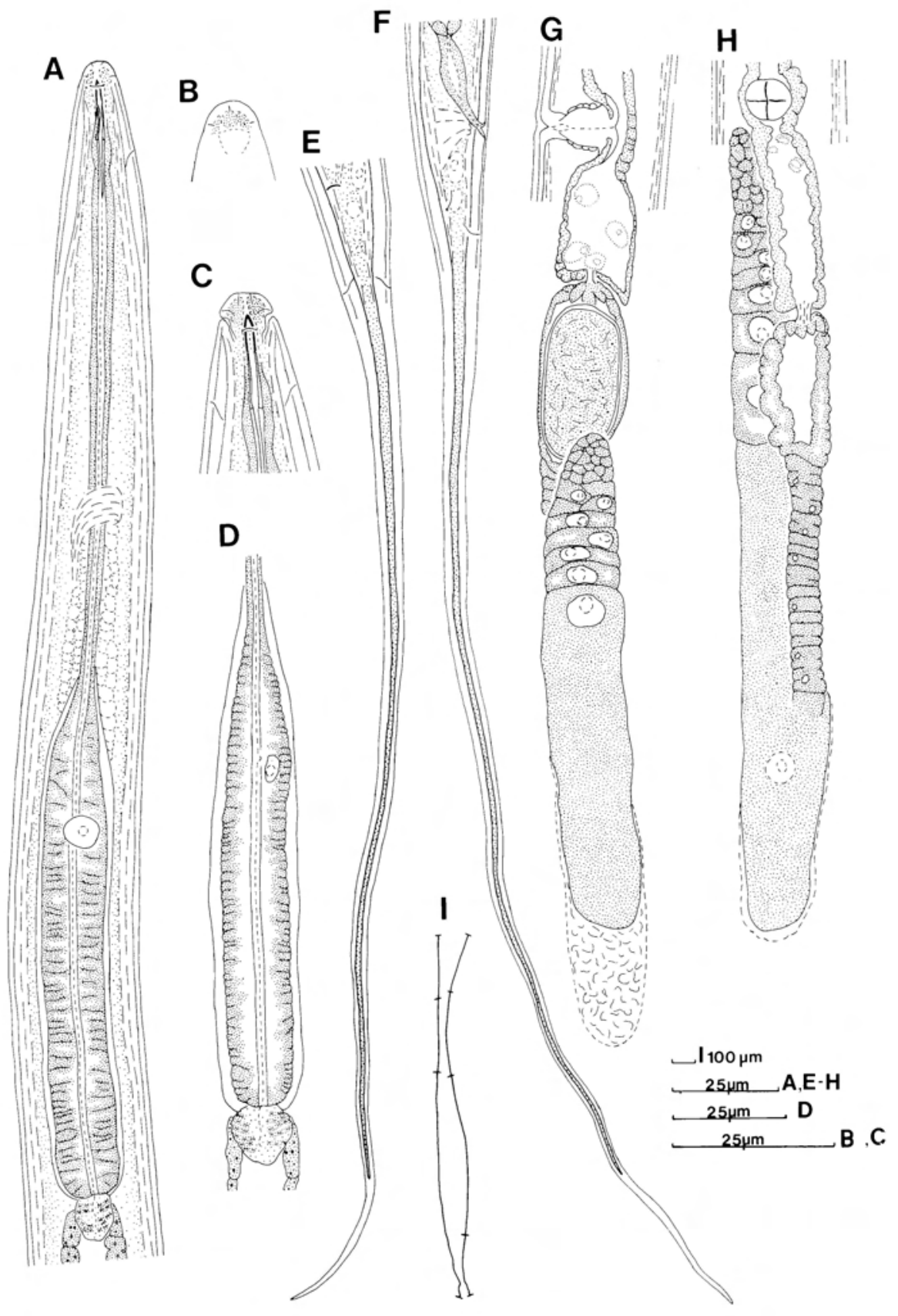

Fig. I Orvdirus gangeticus Siddiqi, 1966: A. Anterior body region of female: B. Shape and position of amphid: C. Dorso-ventral view of head; D. Basal bulb of oesophagus; E and F. Female tail: G. and H. Posterior branch of female reproductive system; I. Heat-relaxed body posture of two females. 
Table 2

Morphometric characters of Dorylaimellus (Axodorylaimellus) caffrae (Kruger, 1965)

\begin{tabular}{|c|c|c|}
\hline Locality & Sabie River & $\begin{array}{c}\text { Type population } \\
\text { (According to Siddiqi, 1966) }\end{array}$ \\
\hline$n$ & 6 Females & 3 Females \\
\hline $\mathrm{L}(\mathrm{mm})$ & $0.47(0.41-0.58)$ & $0,44-0,47$ \\
\hline a & $26.4(24-27,6)$ & $26-27$ \\
\hline b & $2.9(2,6-3,4)$ & $2,4-3,0$ \\
\hline $\mathrm{c}$ & $29.5(25.6-38.7)^{(1)=5)}$ & $27-29$ \\
\hline$c^{\prime}$ & $1,4(1,2-1,7)^{(n=5)}$ & - \\
\hline $\mathrm{V} \%$ & $57(54,9-58,4)$ & $57-61$ \\
\hline Lip region width & 5.5 & - \\
\hline Odontostyle length & $5(4,5-5,5)$ & - \\
\hline Length of spear extensions & $9(7.5-10)$ & - \\
\hline Amphid aperture & $5^{(n=5)}$ & - \\
\hline Nerve ring from anterior end & 50 & - \\
\hline Oesophagus length & $159.5(150-167)$ & - \\
\hline Distance from head to vulva & $27(23-33)$ & - \\
\hline $\begin{array}{l}\text { Tail length } \\
\text { Tat }\end{array}$ & $16(15,5-16,5)^{(n=5)}$ & - \\
\hline Anal body width & $11,5(10-13)^{(1)=5)}$ & - \\
\hline Rectum length & $14(11-17,5)^{(n=3)}$ & - \\
\hline Prerectum length & $33(21,5-45)^{(1 / n=3)}$ & - \\
\hline Cuticle width: on the neck & 1 & - \\
\hline : at mid-body & $1(1-1.5)$ & - \\
\hline : at dorsal side of tail & $1(1-1,5)$ & - \\
\hline : around tail tip & $3,5(3-4)$ & - \\
\hline
\end{tabular}

papillae not very well developed, apparently two pairs of papillae present, one pair situated ventrally slightly more than one anal body diameter from anus and another pair sublaterally about one anal body diameter from anus.

Female didelphic, amphidelphic (Fig. 1G \& H). Ovaries distinct, reflexed. Pars dilatata oviductus separated from uterus by a prominent sphincter muscle. Oviduct long and well-developed with about 20 relatively distinct cells. Uterus short, not differentiated into ovejector and pars dilatata. Vagina muscular, reaching $55-58 \%$ of the corresponding body diameter. Vulva a transverse slit, 5-6 $\mu \mathrm{m}$ long, without sclerotized labia. One egg observed in pars dilatata oviductus measuring $34,5 \mu \mathrm{m} \times 17 \mu \mathrm{m}(n=1)$. No sperm cells observed in uterus.
Male not found.

\section{Remarks}

The original description of Oxydirus gangeticus was based on females collected from soil around the roots of grass on the bank of the Ganges River, India by Siddiqi (1966). The present specimens from the Kruger National Park are similar to the types except for a slightly larger a-ratio $(\mathrm{a}=46,9-52,5$ compared with $\mathrm{a}=41-45)$; and a slightly larger $c^{\prime}$-ratio $\left(c^{\prime}=12,3-15,6\right.$ compared with $12-$ 13). It is also very similar to the specimens from Indiana (Ferris et al. 1980) except for a longer tail (242,5-304 $\mu \mathrm{m}$ compared with 224-249,6 $\mu \mathrm{m}$ ), a slightly more anteriorly situated vulva $(\mathrm{V}=30,9-39,9 \%$ compared with $\mathrm{V}=37-39 \%$ ), a slightly shorter odontophore (9-11,5 $\mu \mathrm{m}$ compared with 15 
Table 3

Morphometric characters of Laimydorus af ricanus spec. nor:

\begin{tabular}{|c|c|c|c|}
\hline \multirow[t]{2}{*}{ Locality } & \multicolumn{3}{|c|}{ Levuvhu River } \\
\hline & \multirow{2}{*}{$\frac{\text { Holotype }}{\text { Female }}$} & \multicolumn{2}{|c|}{ Paratypes } \\
\hline$n$ & & 3 Females & 2 Males \\
\hline $\mathrm{L}(\mathrm{mm})$ & 1.40 & $1,45(1,43-1,47)$ & $1.34: 1.32$ \\
\hline a & 33,3 & $31(29,1-33,3)$ & $33.5: 34.3$ \\
\hline$a^{\prime}$ & 38,9 & $40,3(39,2-41.7)$ & 41,$2 ; 41,3$ \\
\hline b & 4.6 & $5,0(4,9-5,1)$ & $5.6: 4.4$ \\
\hline c & 15,2 & $14,7(13,7-15.9)$ & $89.3: 94.3$ \\
\hline $\mathrm{c}^{\prime}$ & 5,3 & $5,6(5,3-5,9)$ & $0.8: 0.7$ \\
\hline $\mathrm{V} \%$ & 44,3 & $46,8(45,6-47,9)$ & $-\quad:-$ \\
\hline Lip region width & 8 & $8(8-9)$ & $8.5: 9$ \\
\hline Odontostyle length & 18 & $11.5(16.5-18)$ & $18: 16$ \\
\hline Odontostyle width & 2 & 2 & $2: 2$ \\
\hline Odontophore length & 18 & $16(14-17.5)$ & $12.5: 14$ \\
\hline Odontostyle aperture & 4 & $5(5-5,5)$ & $5.5: 4.5$ \\
\hline Stylet aperture as \% of stylet length & 22,2 & $29(27,8-30,3)$ & $27.8: 28.1$ \\
\hline Guiding ring from anterior end & 10 & $10(10-11)$ & $10: 11$ \\
\hline Amphid aperture & & & $-\quad:-$ \\
\hline Nerve ring from anterior end & 121 & $119,5(112-124)$ & $107.5 ; 115,5$ \\
\hline Oesophagus length & 305 & $287(280-300)$ & $240: 300$ \\
\hline Body width & 42 & $47(43-50,5)$ & $40: 38.5$ \\
\hline Tail length & 92 & $99(90-107)$ & $15: 14$ \\
\hline Anal body diameter & 17.5 & $18(17-19)$ & $19 ; 20$ \\
\hline Rectum length & 30.5 & $37(35.5-38.5)$ & $-\quad:-$ \\
\hline Prerectum length & 65 & $72(64-78)$ & $224: 190$ \\
\hline Spiculas length & - & - & $39: 38.5$ \\
\hline Length of lateral guiding pieces & - & - & $7: 8.5$ \\
\hline \multicolumn{4}{|l|}{ Number of ventromedian } \\
\hline supplements & - & - & $18: 19$ \\
\hline Number of subventral papillae & - & - & $11 ; 11$ \\
\hline
\end{tabular}

$\mu \mathrm{m})$ and a slightly longer basal bulb (99-129 $\mu \mathrm{m}$ compared with 99,2-105,6 $\mu \mathrm{m}$ ).

Locality and habitat

Ten females collected from three different localities in the Sabie River: in sand from the river bank between the Nkuhlu picnic-area and Lower Sabie Camp, in sand between Phragmites just east of Skukuza Camp, and in river sediment near the weir of the Lisbon Estates, collected by A. Botha and J. Heyns in February, 1990.
Specimens

Specimens on slides W2542, W2557, W2571, W2573, W2644, W2645 and W2660.

Family: Dorylaimellidae (Jairajpuri, 1964) Thorne, 1964

Dorylaimellus (Axodorylaimellus) caffrae (Kruger, 1965) Jairajpuri \& Ahmad, 1980.

Morphometric data in Table 2.

The original description of Dorylaimellus (Axodorylaimellus) cafficae was based on specimens collected in agricultural fields and 
compost heaps in several localities in South Africa (Kruger 1965). The present specimens from the Kruger National Park agree well with the type population except for a slightly longer body $(\mathrm{L}=0,41-0,58 \mathrm{~mm}$ compared with $\mathrm{L}=0,44-0,47 \mathrm{~mm})$, a slightly larger c-ratio $(\mathrm{c}=25,6-38,7$ compared with $\mathrm{c}=27$ 29) and a slightly more anteriorly situated vulva $(\mathrm{V}=54,9-58,4 \%$ compared with $\mathrm{V}=57-61 \%)$.

\section{Locality and habitat}

Specimens from two sampling points in the Sabie River: from sand among the roots of Phragmites near the weir east of the Lower Sabie Camp and in sand just east of Skukuza Camp, collected by A. Botha and J. Heyns in February, 1990.

\section{Specimens}

Specimens on slides W2584, W2598 and W2654.

Family: Dorylaimidae De Man, 1876

Laimydorus africanus spec. nov. (Fig. 2A-I).

Morphometric data in Table 3.

Female

Medium-sized nematode with relatively slender body. Heat-relaxed body posture almost straight (Fig. $2 \mathrm{H}$ ). Cuticle thin: $2-2,5 \mu \mathrm{m}$ on the neck; $2-3 \mu \mathrm{m}$ at mid-body and $2-3 \mu \mathrm{m}$ at dorsal side of tail. Exocuticle with faint transverse striae. Lateral chords about one fourth as wide as body at base of oesophagus; granular and with small cells. Lateral, dorsal and ventral body pores obscure.

Lip region set of by a shallow constriction, about one fifth to one fourth as wide as body at base of oesophagus. Lips amalgamated and rather angular in outline, with protruding papillae (Fig. 1A-C). Amphid stirrup-shaped, its aperture slightly more than one half the lip region width. Odontostyle distinct and slender. about twice as long as lip region width, its aperture slightly less than one third stylet length. Stylet width about one ninth stylet length. Odontophore not very distinct, about equal to stylet in length. Guiding ring appearing double, weakly sclerotized. Hemizonid situated posterior to nerve ring, which is situated at 112-124 $\mu \mathrm{m}$ from anterior end. Basal bulb of oesophagus enveloped by a thin muscular sheath. Cardia elongate-conoid, variable in length (Fig. 1A \& D). Oesophageal gland nuclei not observed; openings of glands observed in one female $(n=1)$ $\mathrm{DO}=61,2 ; \quad \mathrm{S}_{1} 0_{2}=78,2 ; \quad \mathrm{S}_{2} 0_{1}=90,1$; $\mathrm{S}_{2} \mathrm{O}_{2}=90,5 ; \mathrm{S}_{1} 0_{1}$ obscure.

Intestine about eight cells in circumference, cells packed with numerous small to large yellowish-brown granules. Junction between intestine and prerectum distinct. Sphincter at junction of prerectum and rectum relatively well-developed. Prerectum length about $3,7-$ 4,8 times anal body diameter. Rectum length about 1,7-2,3 times anal body diameter. Anal muscles relatively prominent, consisting of four to five bands. Tail elongate-conoid with an acute terminus (Fig. 2 F). Only one pair of caudal papillae observed, situated laterally at about one and a half anal body diameters posterior to anus. Hyaline part of tail tip varies from $19-25 \mu \mathrm{m}$ in length.

Female didelphic, amphidelphic (Fig. 2G). Ovaries very long, distinct and reflexed. Ovary of posterior reproductive branch of one female reflexed twice (second flexure of ovary at germinal zone). Oviduct relatively short but well-developed. The pars dilatata oviductus, which is large and packed with sperm cells, is separated from the uterus by a weakly developed sphincter muscle. Uterus relatively long, divided into three parts: first part nearest to vagina, long and wide and packed with sperm cells; the second part forms a weakly developed z-differentiation (Fig. 2G), with strongly muscular walls and weakly sclerotized structures in the lumen; and the third part a weakly developed pars dilatata uteri, which is packed with sperm cells. Ovejector not clearly differentiated. Vagina muscular, reaching about $64 \%$ of the 


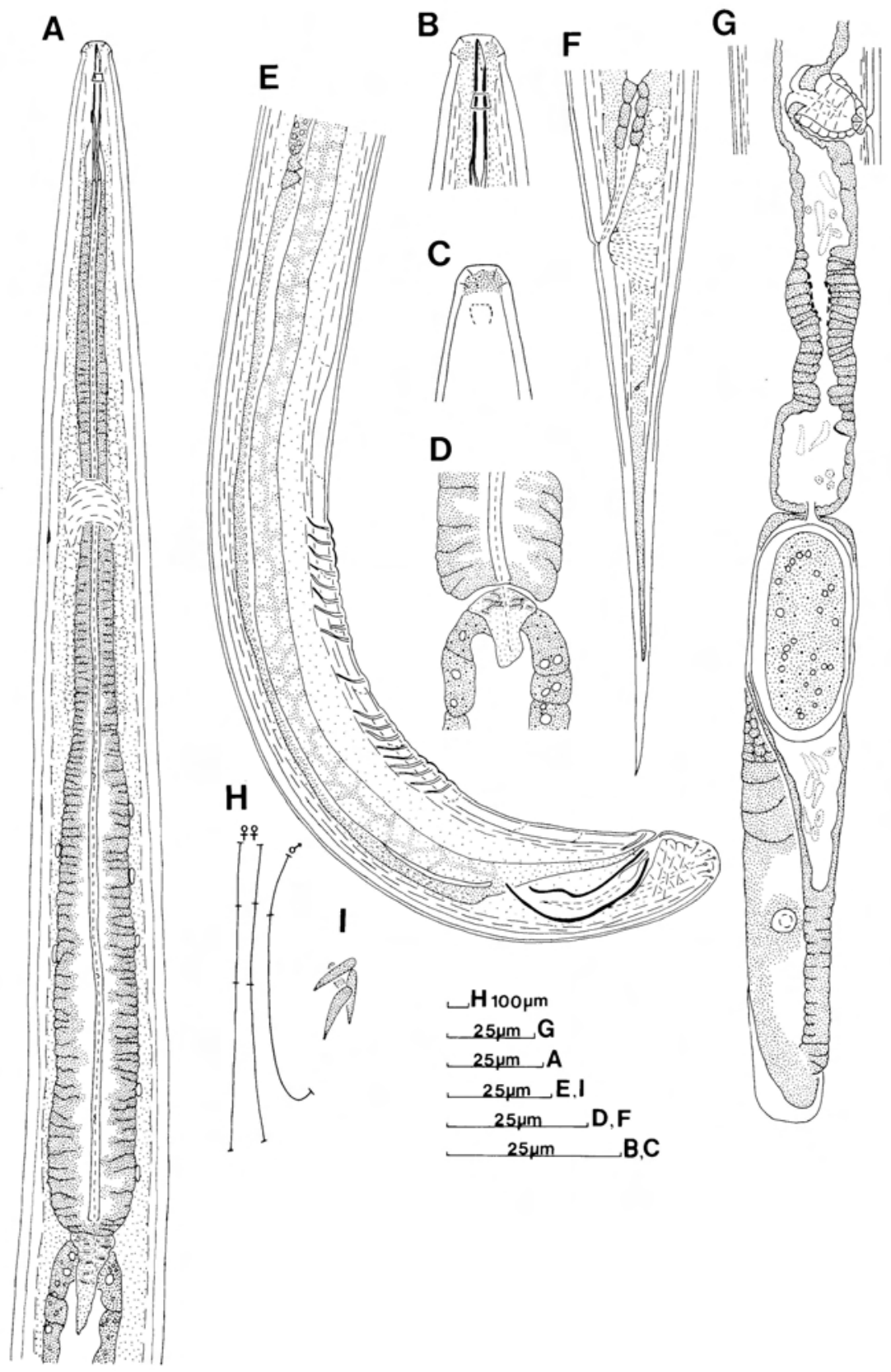

Fig. 2. Laimydorus africanus spec. nov: A. Anterior body region of female; B. Lateral view of head region: C. Shape and position of amphid; D. Cardiac region; E. Posterior region of male body; F. Female tail; G. Posterior branch of female reproductive system; H. Heat-relaxed body posture of two females and one male; I. Sperm cells. 
corresponding body diameter. Weakly sclerotized pieces present between vagina and vulva. Vulva a small longitudinal slit. Uterus with one egg at a time, measuring $57-62 \mu \mathrm{m} \times 22,5-23 \mu \mathrm{m}(n=4)$, and one egg observed in pars dilatata oviductus of one female. Eggs measure 55-65 $\mu \mathrm{m} \times 22-23 \mu \mathrm{m}$ $(n=3)$. Measurements exclude width of egg shell, which varies from $2,5 \mu \mathrm{m}$ to $4 \mu \mathrm{m}$.

Male

Male similar to female except posterior part of body may be more strongly ventrally curved, in the shape of the letter J (Fig. 2H). Male diorchic, testes opposed and outstretched; anterior testis reaching base of oesophagus. Length of posterior and anterior testes 250,5-342 $\mu \mathrm{m}$ and 286-339 $\mu \mathrm{m}$ respectively. Sperm cells elongate, acute at one end and bluntly rounded at other end, 12-14 $\mu \mathrm{m}$ long (Fig. 2I). Spicules relatively slender, $38,5-39 \mu \mathrm{m}$ long. Lateral guiding pieces $7-$ $8,5 \mu \mathrm{m}$ long. Supplements consisting of an adanal pair and 18-19 ventromedians, the latter arranged in two fascicles with a solitary supplement between the fascicles; the anterior fascicle consisting of nine and posterior fascicle of eight to nine contiguous supplements. Subventral papillae 11 pairs irregularly spaced, extending $36,5 \mu \mathrm{m}$ beyond anterior fascicle. Copulatory muscles reaching just beyond subventral papillae. Prerectum-intestine junction situated far beyond anterior fascicle. Tail convex-conoid, with a bluntly rounded terminus (Fig. 2E). Seven pairs of caudal papillae present near the terminus. Prerectum length 9,5-11,8 times anal body diameter.

\section{Diagnosis}

Laimydorus africanus spec. nov. has a relatively short body with a long and slender odontostyle. Female reproductive system with weakly developed z-differentiation and weakly sclerotized pieces between vagina and vulva. The ventromedium supplements of male arranged in two fascicles with a solitary supplement between the two fascicles.

\section{Differential diagnosis}

Laimydorus africanus spec. nov. is close to L. cryptosperma (Loof, 1969) Baqri \& Coomans, 1973 and L. stenopygus (Andrássy, 1968) Siddiqi, 1969. It differs from $L$. cryptosperma by having a shorter body (Female: $\mathrm{L}=1,40-1,47 \mathrm{~mm}$ vs. $\mathrm{L}=1,94-2,30$ $\mathrm{mm}$; Male: $\mathrm{L}=1,34 \& 1,32 \mathrm{~mm}$ vs. $\mathrm{L}=1,80-2,13 \mathrm{~mm}$ ), a larger c-ratio (Female: $\mathrm{c}=13,7-15,9$ vs. $\mathrm{c}=10-12 ;$ Male: $\mathrm{c}=89,3$ \& 94,3 vs. $c=64-84)$; a shorter odontostyle (16-18 $\mu \mathrm{m}$ vs. 20-22 $\mu \mathrm{m})$; a shorter odontophore $(12,5-18 \mu \mathrm{m}$ vs. $33-35 \mu \mathrm{m})$; smaller eggs $(55-65,8 \mu \mathrm{m} \times 22-23 \mu \mathrm{m}$ vs. 71-90 $\mu \mathrm{m} \times 31-36 \mu \mathrm{m})$; shorter spicules (39 \& $38,5 \mu \mathrm{m}$ vs. $52-58 \mu \mathrm{m})$; shorter lateral guiding pieces ( $7 \& 8,5 \mu \mathrm{m}$ vs. $16 \mu \mathrm{m})$, less ventromedian supplements ( 18 \& 19 vs. 21 25 ), less subventral papillae ( 11 pairs vs. 14 pairs) and the lips are amalgamated with protruding papillae compared with well-developed lips without protruding papillae.

Laimydorus africanus spec. nov. differs from L. stenopygus by being shorter (Female: $\mathrm{L}=1,40-1,47 \mathrm{~mm}$ vs. $\mathrm{L}=1,90-2,22 \mathrm{~mm}$ ) and by having a larger b-ratio (Female: $\mathrm{b}=4,6-5,1$ vs. $\mathrm{b}=4,0-4,3)$; Male: $\mathrm{b}=5,6$ \& 4,4 vs. $b=4,0-4,2$ ); a larger c-ratio (Female: $\mathrm{c}=13,7-15,9$ vs. $\mathrm{c}=11,1-11,5) ;$ a shorter odontostyle (16-18 $\mu \mathrm{m}$ vs. $25-29 \mu \mathrm{m})$; a shorter odontophore $(12,5-18 \mu \mathrm{m}$ vs 32-34 $\mu \mathrm{m})$; larger eggs $(55-65 \mu \mathrm{m} \times 22-23 \mu \mathrm{m}$ vs. 30-35 $\mu \mathrm{m} \times 16-18 \mu \mathrm{m}$ ); smaller spicules (39 $\& 38,5 \mu \mathrm{m}$ vs. $48-50 \mu \mathrm{m})$; and less ventromedian supplements ( 18 \& 19 vs. $28-29$ ).

Laimydorus africanus spec. nov. differs also from the abovementioned species by the presence of a $z$-differentiation in the uterus. This is the first time that a $z$-differentiation is observed in a Laimydorus species.

Type locality and habitat

Type specimens collected from a stagnant pool east of Pafuri by J. Heyns in February, 1991. 
A

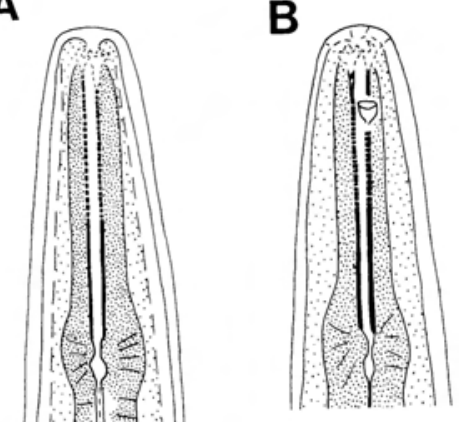

C

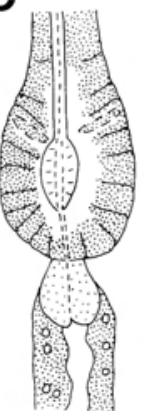

D
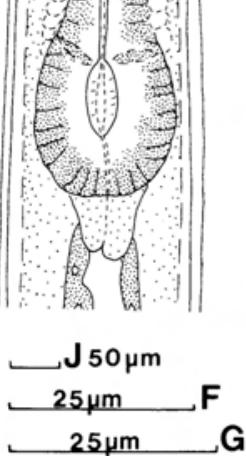

$25 \mu \mathrm{m}$
E
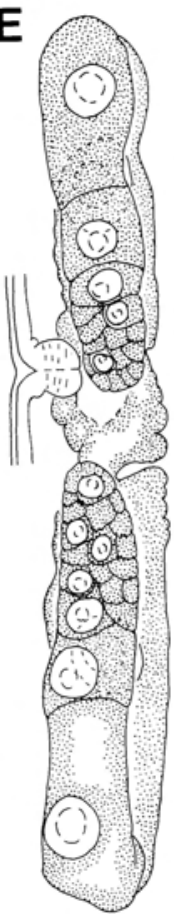

H

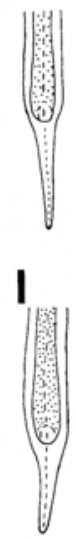

F
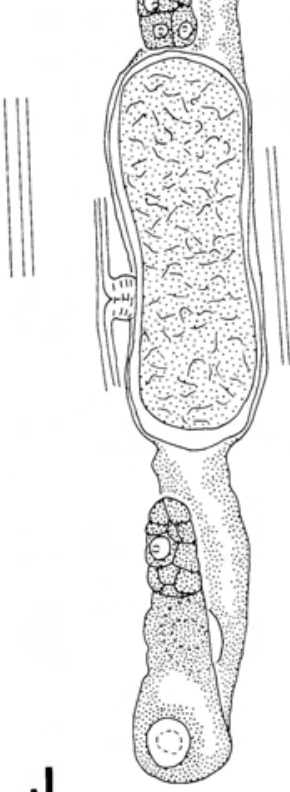

G

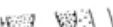


Table 4

Morphometric characters of Rhabdolaimus terrestris De Man, 1880

\begin{tabular}{|c|c|c|}
\hline & Sabie River & According to Khera (1972) \\
\hline$n$ & 10 Females & 4 Females \\
\hline $\mathrm{L}(\mathrm{mm})$ & $0.57(0.44-0.64)$ & $0.49-0.56$ \\
\hline a & $24,8(23,1-28,1)$ & $23-25$ \\
\hline b & $4.9(4,0-5,4)$ & $4,5-5,1$ \\
\hline $\mathrm{c}$ & $3.9(3,7-4,1)$ & $3,5-4$ \\
\hline$c^{\prime}$ & $8,1(7,5-9,4)$ & - \\
\hline $\mathrm{V} \%$ & $41,9(40.5-44.8)$ & $39-43$ \\
\hline Lip region width & $8(7.5-10)$ & - \\
\hline Stoma length & $29.5(27-32.5)$ & - \\
\hline Stoma width & 1,5 & - \\
\hline Amphid & $2^{(n=1)}$ & - \\
\hline Hemizonid from anterior end & 73,$5 ; 77,5$ & - \\
\hline Oesophagus length & $112(105-117,5)$ & - \\
\hline Basal bulb length & $20(18-23)$ & - \\
\hline Basal bulb width & $14.5(13,5-16,5)$ & - \\
\hline Body width & $22(19-26)$ & - \\
\hline Distance from head to vulva & $23(19.5-26)$ & - \\
\hline Vagina length & $8(7-9)$ & - \\
\hline Tail length & $143(115.5-160.5)$ & - \\
\hline Anal body diameter & $18(15-20)$ & - \\
\hline Rectum length & $11(9-12)$ & - \\
\hline Spinneret length & $10(9-12)$ & - \\
\hline Egg: length & $55.5^{(\prime \prime=1)}$ & - \\
\hline width & $17^{(n=1)}$ & - \\
\hline
\end{tabular}

Type specimens

Holotype on slide W2840; paratypes on slide W2859.

Family: Rhabdolaimidae Chitwood, 1951

Rhabdolaimus terrestris De Man, 1880 (Fig. 3A-J).

Morphometric data in Table 4.

Female

Relatively small nematode, with robust body. Heat-relaxed body posture almost straight to slightly ventrally curved posteriorly (Fig. 3J). Cuticle thin: $1-1,5 \mu \mathrm{m}$ on the neck; $1-2 \mu \mathrm{m}$ at mid-body, and $2 \mu \mathrm{m}$ on dorsal side of tail. Exocuticle appearing smooth; subcuticle with faint transverse striae. Lateral chords slightly more than one fourth as wide as body at base of oesophagus; granular with small cells.

Lip region confluent with body, about one fifth to one fourth as wide as body at base of oesophagus (Fig. 3A \& B). Lips fused and rather rounded in outline. Papillae indistinct. Amphid narrow, stirrup-shaped, situated at about $9 \mu \mathrm{m}$ from anterior end, its aperture very small, and indistinct. Stoma tubular, its walls sclerotized and the anterior half of stoma walls striated. Posterior to the base of the stoma there is a small interruption in the normal countour of the oesophageal lumen (Fig. 3A \& B). Small denticles present at anterior end of stoma.

Anterior part of oesophagus almost cylindrical, expanding slightly in region of stoma base to form a short probulbus. Basal bulb of oesophagus muscular with a valve apparatus. 
Walls of valve striated. At the anterior end of the valve there is a transverse interruption in the musculature of the basal bulb. Cardia about one third as long as body width at base of oesophagus (Fig. 3C \& D). Hemizonid situated opposite nerve ring.

Intestine about six cells in circumference, cells with medium-sized light green granules. Rectum length about $0,5-0,7$ times anal body diameter. Tail elongate-conoid, tapering gradually to a bluntly rounded terminus (Fig. 3G). Three well-developed caudal glands present, lying in tandem, opening with a duct in a terminal spinneret, varying in length (Fig. $3 \mathrm{H} \& \mathrm{I})$.

Female didelphic, amphidelphic (Fig. 3E \& F). Genital system short. Ovaries reflexed ventrally or dorsally, relatively well-developed. Oviduct broad, cells not clearly differentiated; part nearest to vagina slightly expanded, no distinct pars dilatata oviductus or sphincter observed. Uterus when not containing an egg, very short and indistinct. Vagina strongly muscular. Vulva a small transverse slit. One egg observed in uterus, measuring $55,5 \mu \mathrm{m} \times 17 \mu \mathrm{m}$.

\section{Remarks}

Rhabdolaimus terrestris is a cosmopolitan species which was first reported from the Netherlands (De Man 1880). The specimens from the Kruger National Park agree more closely with the specimens reported from India by Khera (1972). They differ from the Indian population by being slightly longer ( $\mathrm{L}=0,44-0,64 \mathrm{~mm}$ vs. $\mathrm{L}=0,49-0,56 \mathrm{~mm}$ ) and having slightly larger eggs $(55,5 \mu \mathrm{m} x$ $17 \mu \mathrm{m}$ vs. $48 \mu \mathrm{m} \times 15 \mu \mathrm{m}$ ).

In view of the magnitude of variation reported in different populations of $R$. terrestris and the possibility that we may be dealing with a group of closely-related species, we considered it best to give a full description of our specimens.
Locality and habitat

Specimens collected in three sampling points in the Sabie River, namely: in river sediment east of the confluence of the Nwatindlopfu Spruit and Sabie River, in water and sand among the roots of Phragmites near the confluence of the Sabie Rivers, and in sand among the roots of Phragmites just east of Skukuza Camp; all collected by A. Botha and J. Heyns in February 1990.

\section{Specimens}

Specimens on slides W2606, W2608, W2609, W2631, W2633, W2634 and W2652.

\section{References}

Baqri. O.H. And A. Coomans. 1973. A taxonomic revision of the nematode species described by $\mathrm{S}$. Stekhoven \& Teunissen (1938) and S. Stekhoven (1944) from National Virunga Park (Zaïre Republic). I. Dorylaimidae, Aporcelaimidae and Longidoridae. Exploration du Parc National des Virunga 1: 1-57.

Botha, Annelize and J. Herns. 1991. Dorylaimoidea (Nematoda) from rivers in the Kruger National Park. Koedoe 34(2): 1-24.

Botha, Annelize and J. Heyns. 1992a. Freshwater nematodes of the genera Thornenema and Mesodorylaimus from the Kruger National Park with a diagnostic species compendium for South African species of the genus Mesodorylaimus (Nematoda: Dorylaimida). Koedoe 35(1): 25 42.

Botha. Annelize and J. Heyns. 1992b. Species of Tyleptus, Proleptonchus, Aquatides and Afractinolaimus from rivers in the Kruger National Park (Nematoda: Dorylaimida). Koedoe 35(1): 43-54.

Botha, Annelizeand J. Heyns. 1992c. Further records and descriptions of nematodes from rivers in the Kruger National Park (orders Enoplida, Chromadorida, Monhysterida, Mononchida and Araeolaimida). Koedoe 35(2): 11-25.

DE MAN, J.G. 1880. Die Einheimischen, frei in der reinen Erde und im süssen Wasser lebende Nematoden. Tydschrift der Nederlandsche Dierkundige Vereeniging 5(1/2): 1-104.

Ferris, V.R., C.G. Goseco and J.M. Ferris. 1980. Revisions of Orydirus and Tarjanius n.gen. in Oxydiridae, Belondiroidea (Nematoda: Dorylaimida) and Oxydiroides in Prodorylaimidae. Dorylaimida. Research Bulletin of the Agricultural Experiment Station Perdue University 965: 1-29. 
KherA, S. 1972. Nematodes from the banks of still and running waters. 12. Order Araeolaimida. Proceedings of the Zoological Society of Calcutta 25(1): 49-58.

Kruger, S.P. 1965. New species of the genera Tylencholaimus and Dorylaimellus from South Africa. Proceedings of the Helminthological Societs of Washington 32(1): 1-20.
SidDIQI, M.R. 1966. Studies on species of Belondiroidea (Nematoda: Dorylaimida) from India. Proceedings of the Helminthological Society of Washington 33(2): 139 - 157.

SiddiQI, M.R. 1969. Mumtazuim mumtazae n.gen.. n.sp. (Nematoda: Tylencholaimidae) with the proposal of Laimydorus n.gen. (Thornenematidae). Nematologica 15(2): 234-240. 